УАК 616.314.17-02-092: 616.314.26-007

(с)О. О. Фастовець, В. Г. Малиновський

А,3 «Аніпропетровська медична академія МОЗ України»

\title{
Оклюзійна травма та захворювання пародонта (огляА літератури)
}

Резюме. У даній статі представлено огляд літератури щодо вивчення проблеми впливу оклюзійної травми на розвиток захворювань пародонта. Описані сучасні гіпотези розвитку запальнодистрофічного процесу в пародонті під впливом оклюзійних порушень. Вказано на спірність питання можливості первинної ініціації пародонтиту дією оклюзійного перевантаження. Зазначено неоднозначність підходів щодо необхідності, а також порядку проведення заходів оклюзійної корекції в комплексному лікуванні пародонтиту, що потребує подальших наукових досліджень.

Ключові слова: оклюзійна травма, захворювання пародонта.

\author{
Е. А. Фастовец, В. Г. Малиновский \\ ГУ «Анепропетровская медицинская академия МЗ Украины»
}

\section{Окклюзионная травма и заболевания пародонта (обзор литературы)}

Резюме. В данной статье представлен обзор литературы по изучению влияния окклюзионной травмы на развитие заболеваний пародонта. Описаны современные гипотезы развития воспалительнодистрофического процесса в пародонте под влиянием окклюзионных нарушений. Указано на спорность вопроса возможности первичной инициации пародонтита влиянием окклюзионной перегрузки. Обозначена неоднозначность подходов касательно необходимости, а также порядка проведения мероприятий окклюзионной коррекции в комплексном лечении пародонтита, что требует дальнейших научных исследований.

Ключевые слова: окклюзионная травма, заболевания пародонта.

\author{
O. O. Fastovets, V. H. Malynovsky \\ SI «Dnipropetrovsk Medical Academy of MPH of Ukraine»
}

\section{Occlusial trauma and periodontal diseases (literature review)}

Summary. This article reviews the literature on the effect of occlusial trauma on the development of periodontal disease. The modern hypothesis of pathogenesis of inflammatory degenerative process in the periodontium under the influence of occlusial disorders has been described. They indicated on debatable question of the possibility of primary initiation of periodontitis by occlusial overload. They denoted the ambiguity of approaches on the need, as well as the order of occlusial correction in the complex treatment of periodontitis, which requires the further research.

Key words: occlusial trauma, periodontal diseases. 
Захворювання пародонта пов'язують з оклюзійною травмою протягом багатьох років. Перша піонерська робота цього напрямку була опублікована Karolyi у 1901 році та мала назву «Beobachtungen uber Pyorrhoea alveolaris» («Оклюзійний стрес та альвеолярна піорея»). Проте незважаючи на велику кількість досліджень, проведених від того, роль оклюзії в етіології і патогенезі запальних захворювань пародонта досі не зрозуміла [20].

На сьогодні оклюзійна травма позиціонується як пошкодження пародонта в результаті дії оклюзійних сил, що перевищують його репаративну здатність. Оклюзію, що призводить до такого пошкодження пародонта, називають травматичною та буває хронічною та гострою. Гостра травма від оклюзії може бути результатом накушування, нераціональних реставрацій або зубних протезів. Хронічна оклюзійна травма зустрічається частіше і розвивається паралельно з поступовими змінами змикання зубів. Вторинна травматична оклюзія спостерігається у тих випадках, коли здатність до адаптації тканин пародонта порушується в результаті втрати кісткової маси внаслідок запально-дистрофічних процесів у пародонті [25].

Поруч з тим, на даний час немає єдиної думки про роль оклюзійних порушень в етіопатогенезі генералізованого пародонтиту. Аумки розділилися: одні стверджують про зв'язок між оклюзійною травмою та ініціацією захворювань пародонта, інші - його заперечують. Незважаючи на значний обсяг публікацій 3 оклюзійної корекції, питання про те, чи може оклюзійна травма вплинути на перебіг патологічного процесу в пародонті, залишається не з'ясованим [2].

На думку низки вчених, оклюзійні розлади безумовно здатні сприяти руйнуванню періодонтальної зв'язки. При цьому оклюзійні сили можуть викликати зміни в альвеолярній кістці та в періодонті як при наявності, так і за відсутності пародонтиту, тоді як самі по собі ініціювати пародонтит не здатні. Зміни в пародонті під впливом оклюзійного перевантаження можуть вплинути на рухомість зубів і сприяти формуванню пародонтальних кишень. В цьому контексті слід зазначити існування взаємозв'язку між запальними процесами у пародонті й аномальними оклюзійними контактами $[8,18]$.
Решта вчених не настільки категорична та вказує, що лише в деяких випадках оклюзійні сили сприяють прогресуванню захворювань пародонта [5]. Більш того, причини появи рухомості зубів залежать від цілої низки чинників, зокрема обсягу втрати кісткової маси альвеолярного відростка, ступеня руйнування періодонтальної зв'язки, активності запальних процесів у тканинах пародонта, а також здатності до фізіологічної адаптації у відповідь на оклюзійне навантаження [24].

Сучасне уявлення про розвиток патологічних змін у тканинах пародонта під дією оклюзійного фактора представлено наступним чином. Піддією надмірного механічного напруження внаслідок гіпероклюзії виникає порушення періодонтальної зв'язки і руйнування альвеолярної кістки, що призводить до травматичної оклюзії. Подібні порушення супроводжуються виробленням у тканинах пародонта хемокінів, пов'язаних з остеокластогенезом, в результаті чого активується хемотаксис і остеокластогенез. У моделі in vitro 3 використанням переривчастого навантаження, що розтягує, було показано процес активації експресії CC-хемокінів (CCL2, CCL3 і CCL5) для клітин періодонтальної зв'язки. Рівні викиду CCL2 в тканини пародонта, активація його рецепторів (CCR2) у попередниках остеокластів і TRAP-позитивних клітинах (позитивних до тартратрезистної кислої фосфратази, подібних до остеобластів) в альвеолярній кістці були значно збільшені через 4-7 днів після змодельованого надмірного навантаження при гіпероклюзії в природних умовах на моделях гризунів [14].

Відповідно, усунення активації CCL2/ CCR2-рецепторів пригнічує остеокластогенез, пов'язаний з оклюзійним навантаженням та утворенням хемокінів, а отже, зменшує травматичну оклюзію. Аослідження впливу механічного навантаження на експресію хемокінів і активацію остеокластогенезу проведено на моделях гіпероклюзї in vivo та in vitro у CCL2і CCR2-дефіцитних мишей. Порівняно з дикими мишами, утворення CCL3 та TRAP-позитивних клітин в альвеолярній кістці у CCL2і CCR2-дефіцитних мишей відбувалось навіть при відсутності підвищеного оклюзійного навантаження. Тоді як на четвертий і на сьомий дні експериментальної гіпероклюзії утворення CCL3 та TRAP-позитивних клітин значно

ISSN 231 1-9624. Кпінічна стоматопогія. 2014 . № 2 
збільшувалося. Гіпероклюзія провокувала компенсаторне вироблення CCL3 і сприяла остеокластогенезу для нейтралізації дефіциту CCL2/CCR2-відповіді при допущенні, що одночасний викиА CCL3 та CCL2 може прискорити деструкцію альвеолярної кістки при оклюзійній травмі [15].

Клітини періодонтальної зв'язки здатні не тільки підтримувати остеокластогенез через міжклітинні контакти, а й інгібірувати утворення тартратрезистентної кислої фросфратази TRAP-позитивних багатоядерних клітин шляхом продукції розчинного фактора. Крім того, клітини періодонтальної зв'язки виробляють рецептор-активатор ядерного фактора капа-В ліганд (RANKL) (цитокін сімейства факторів некрозу пухлини) і остеопротегерин мРНК. Виходячи 3 цього, клітини періодонтальної зв'язки під механічним навантаженням відіграють ключову роль у формуванні остеокластів при оклюзійному навантаженні. Було досліджено як механічне напруження впливає на активність клітин періодонта щодо підтримки остеокластогенезу. Періодонтальні клітини знаходились під безперервним стисненням, а потім були культивовані разом з мононуклеарними клітинами периферичної крові протягом 4 тижнів. Було встановлено, що клітини періодонтальної зв' язки під механічним навантаженням регулювали остеокластогенез через мононуклеарні клітини периферичної крові. Крім того, вироблення RANKL мРНК періодонтальними клітинами збільшувалося відповідно до збільшення сили стискання одночасно і паралельно зі зміною кількості остеокластів. Ао того ж силою стискання стимулювалось вироблення циклооксигенази 2 (ЦОГ-2) мРНК. Також була встановлена здатність індометацину інгібувати активність RANKL у результаті стискання. Періодонтальні клітини під дією стискання показали значне збільшення рівня простагландину $\mathrm{E}_{2}$ порівняно з періодонтальними клітинами контролю. У свою чергу, лікування екзогенними простагландинами $\mathrm{E}_{2}$ підвищувало експресію мPHK RANKL для періодонтальних клітин. Цікаво, що експресія остеопротергіну залишалася однаковою протягом стискання або лікування простогландинами. Таким чином, сила стиснення регулює виробку RANKL у періодонтальних клітинах, а RANKL-регуляція в періодонті, що знаходиться під дією ме- ханічного навантаження, залежить від синтезу простагландину $\mathrm{E}_{2}$ [22].

На відміну від стиснення, циклічні рухи, що розтягують, стимулюють вироблення остеопротергіну, також відомого як фактора пригнічення остеокластогенезу в тканинах пародонта, і не викликають остеокластогенезу. В експерименті in vitro клітини періодонтальної зв'язки стимулювались циклічними рухами, що розтягують. Кондиціоноване середовище клітин періодонта, які були піддані циклічній силі, що розтягує, інгібувало остеокластогенез. При цьому циклічні зусилля на розтягання регулюють не тільки вироблення RANKL мPHK, а й PHK остеопротергіну в клітинах періодонта. Силу, яку прикладають, також впливає на вироблення трансформуючого фактора росту - бета. Введення антитіл, що нейтралізують цей фактор, інгібує підвищення вироблення остеопротергіну залежно від дози. Крім того, едект пригнічення остеокластогенезу, кондиційованими середовищами тканин періодонта піддією циклічної сили, що розтягує, частково знижується введенням антитіл, що нейтралізують трансформуючий фактор росту - бета. Таким чином, розтяжне зусилля інгібує активність тканин періодонта щодо активації остеокластогенезу шляхом підвищення рівня остеопротергіну та через стимуляцію вироблення трансформуючого фактора росту - бета [4].

У свою чергу, проведене вивчення змін в мікросудинах і експресії фактора росту ендотелію судин A (VEGF-A) і VEGF рецептора 2 (VEGFR-2) у щурів при гіпофункції періодонтальної зв'язки при експериментальному переміщенні зубів дозволило зробити наступні висновки. Кровонаповнення збільшується на стороні напруження при нормальному функціонуванні зубів. Імунореактивність Аля VEGF-A i VEGFR-2 при нормальній статиці зубів була більшою, ніж при гіпофункції. Стискаюче зусилля швидко викликає апоптоз у періодонтальних тканинах і судинних ендотеліальних клітинах при гіпофункції зубів, чого не спостерігається при нормальних оклюзійних контактах. Як висновок, оклюзійна гіпофункція викликає звуження судин шляхом зменшення експресії VEGF-A і VEGFR-2, а також апоптоз в періодонтальних і судинних клітинах, що відбувається під час рухів зуба [19]. Механічна сила створює під час рухів 
зуба стиснені й безклітинні ділянки в періодонті. При цьому результати проведених досліджень показали, що стиснені клітини періодонтальної зв'язки усуваються шляхом апоптозу в ранній фазі оклюзійного перевантаження зубів [1].

Вплив оклюзійної травми на розвиток захворювань пародонта вивчався не тільки на експериментальних моделях, але й в клініці. Так, дослідження, спрямоване на вивчення впливу оклюзійних сил на резорбцію кісткової тканини пародонта, було проведене серед пацієнтів віком 43-91 років, Аля 88 зубів із патологією пародонта гістологічним методом з використанням оптичного мікроскопа Olympus BX40. Встановлено, що наявність оклюзійного контакту прискорює резорбцію альвеолярної кістки, тим самим ускладнює перебіг пародонтиту [3].

Проведена оцінка зв'язку між вторинною травматичною оклюзією і тяжкістю запально-дистрофічного процесу в пародонті серед 288 пацієнтів із хронічним пародонтитом різного ступеня тяжкості та 93 здорових. При цьому при обстеженні хворих визначали передчасні та балансуючі міжзубні контакти Аля всіх видів оклюзії. Статистично значущі відмінності було знайдено для всіх груп спостереження $(\mathrm{p}<0,001)$. Тобто загальна кількість випадків травматичної оклюзї̈ на одного пацієнта та кількість передчасних і балансуючих контактів значно збільшувалась відповідно до рівня клінічної втрати прикріплення. Внаслідок проведеного дослідження встановлена статистично значуща кореляція між порушеннями оклюзійних співвідношень і тяжкістю патологічного процесу в пародонті $(\mathrm{p}<0,001)$ [26].

За результатами клінічного спостереження 85 пацієнтів із генералізованим пародонтитом (2219 зубів) було теж доведено, що характер оклюзійних контактів відіграє на тяжкості перебігу запального процесу в пародонті. У хворих з оклюзійними розладами було зареєстровано значно більшу глибину пародонтальних кишень: при передчасних контактах в центральній оклюзії - 0,89 мм (p<0,0001), при задніх протрузійних контактах - 0,51 мм $(\mathrm{p}<0,0001)$, при контактах, що балансують, 1,01 мм ( $<0,0001)$, при гіпербалансуючих контактах $-1,13$ мм $(\mathrm{p}<0,0001)$. Таким чином, було показано, що характер оклюзійних кон- тактів відіграє на тяжкості перебігу запальноАистрофічного процесу в пародонті [12].

Разом з тим, навпаки, за результатами дослідження 32 хворих на генералізований пародонтит не встановлено будь-якого істотного розходження показників глибини зондування пародонтальних кишень, наявності зубних відкладень, або ступеня втрати висоти міжальвеолярних перегородок, при наявності та відсутності різних аномальних оклюзійних контактів (передчасних центричних контактів, неробочих контактів у бічних екскурсіях нижньої щелепи, передчасних контактах передніх зубів або бокових зубів при протрузії) [16].

Інтерес до проблеми впливу оклюзї̈ на пародонт активізувався останнім часом у зв'язку із розвитком імплантології, хоча і тут дані проведених досліджень досить суперечливі. Так, для зубних імплантатів доведений зв'язок між оклюзійним перевантаженням та розвитком періімплантиту, а також втратою кісткової тканини навколо імплантата, що відбувається навіть при відсутності запалення [7]. Тоді як, згідно з результатами досліАження на тваринах, не виявлено зв'язку між перевантаженням і втратою кісткової маси навколо імплантата через відсутність періімплантиту, разом з тим, як при його наявності, перевантаження посилює руйнування періімплантної тканини. Як висновок, ефект впливу оклюзійного перевантаження імплантата на втрату кісткової маси в клінічно добре інтегрованих імплантатів не доведений. У моделі на тваринах «перевантаження», що імітує передчасні оклюзійні контакти для періімплантного середовища без запалення, на остеоінтеграцію негативно не впливає, навіть анаболічно. На противагу цьому, супраоклюзійні контакти при наявності запалення значно збільшують індуковану зубним нальотом резорбцію кістки [17].

Виходячи із зазначених протиріч щодо ролі оклюзійних порушень на розвиток пародонтиту, досить суперечливими є погляди на необхідність оклюзійної корекції в комплексному лікуванні захворювання [6, 11, 28].

З одного боку, правильна оклюзійна корекція сприяє підтримці здорового стану пародонта природних зубів пацієнта за рахунок комфортного функціонування. Відповідно рання діагностика оклюзійних порушень, належний 
план лікування та корекція неправильних оклюзійних співвідношень може привести до успішного результату [13]. Отже, на думку низки авторів, лікування генералізованого пародонтиту, доповненого протетичними заходами, має високу ефективність [23]. Тоді як у осіб, в яких заходи оклюзійної корекції не проводили, слід чекати погіршення прогнозу щодо клініко-рентгенологічної стабілізації захворювання. Так, за результатами проведеного дослідження, через рік у осіб, в яких не провоАилась оклюзійна корекція, встановлено суттєво більшу глибину зондування, ніж за умови проведення нормалізації оклюзійних взаємовідношень [13].

Аля вивчення ефективності заходів оклюзійної корекції при генералізованому пародонтиті було проведене довгострокове рандомізоване спостереження. Серед хворих, які не потребували хірургічного втручання, середня різниця в рівні клінічного прикріплення була статистично значущою при проведенні оклюзійної корекції та без неї і складала в середньому $(0,38 \pm 0,04)$ мм на користь оклюзійного втручання. У хірургічній групі середня різниця в рівні клінічного прикріплення при оклюзійному втручанні та при його відсутності склала $(0,40 \pm 0,05)$ мм на користь втручання і також була статистично значущою. Поруч 3 тим, різниця в середньому зменшенні глибини пародонтальних кишень при оклюзійних втручаннях і в контрольній групі як при проведенні хірургічних заходів, так і без них,

\section{Список літератури}

1. Apoptosis of periodontal ligament cells induced by mechanical stress during tooth movement / T. Hatai, M. Yokozeki, N. Funato [et al.] // Oral Diseases. - 2001. - Vol. 7, N. 5. - P. 287-290.

2. Bhola M. Dental occlusion and periodontal disease: what is the real relationship? / M. Bhola, L. Cabanilla, S. Kolhatkar // Journal of California Dental Association. - 2008. - Vol. 36, N. 12. - P. 924-930.

3. Correlation between occlusal contact and root resorption in teeth with periodontal disease / E. Crespo Vøzquez, A. Crespo Abelleira, J. M. Suбrez Quintanilla, M. A. Rodriguez Cobos // Journal of Periodontal Research. - 2011. - Vol. 46, N 1. - P. 82-88.

4. Cyclical tensile force on periodontal ligament cells inhibits osteoclastogenesis through OPG induction / H. Kanzaki, M. Chiba, A. Sato [et al.] // Journal of Dental Research. - 2006. - Vol. 85, N. 5. - P. 457- 462. склала менше ніж 0,1 мм і не була статистично значущою [21].

Поруч з тим, на сьогодні існує думка, що пародонтит можна лікувати без регулювання оклюзії, навіть у присутності травматичної оклюзії. Оклюзійна терапія може бути використана для зменшення рухомості зубів задля відновлення кістки і для лікування різних клінічних проблем, пов'язаних з оклюзійною нестабільністю. Рішення лікаря, чи слід використовувати оклюзійну корекцію, як компонент пародонтологічного лікування, повинне бути пов'язане з оцінкою клінічних фракторів, зокрема повноцінності функції жування, а не повинне грунтуватися на припущенні, що нормалізація оклюзії здатна призупинити прогресування пародонтиту.

У будь-якому випадку слід зазначити певні особливості лікування оклюзійної травми в пародонтології [9]. Безсумнівним є те, що складність оклюзійної корекції полягає у тому, що вона має лише емпіричну базу [27] .

Проведений аналіз літератури вказує на актуальність проблеми ролі оклюзійних порушень у патогенезі захворювань пародонта. Недивлячись на велику кількість досліджень, присвячених цій проблемі, вона залишається не вирішеною. При цьому досить суперечливими є погляди на необхідність заходів оклюзійної корекції в комплексному лікуванні пародонтиту взагалі, а також порядок їх проведення, що потребує подальших наукових розробок.

5. Deas D. E. Is there an association between occlusion and periodontal destruction?: Only in limited circumstances does occlusal force contribute to periodontal disease progression / D. E. Deas, B. L. Mealey // Journal of American Dental Association. - 2006. - Vol. 137, N. 10. - P. 1381, 1383, 1385.

6. Di Benedetto D. C. Occlusion and periodontal disease / D. C. Di Benedetto // Journal of American Dental Association. - 2007. - Vol. 138, N. 1. - P. 28-30.

7. Fu J. H. Occlusion and periodontal disease - where is the link? / J. Y. Fu, A. U. Yap // Singapore Dent al Journal. - 2007. - Vol. 29, N. 1. - P. 22-33.

8. Gher M. E. Changing concepts. The effects of occlusion on periodontitis / M. E. Gher // Dental clinics of North America. - 1998. - Vol. 42, N 2. - P. 285- 299.

9. Green M. S. Occlusion and the periodontium: a review and rationale for treatment / M. S. Green, D. F. Levine // 
Journal of California Dental Association. - 1996. Vol. 24, N 10. - P. 19-27.

10. Harrel S. K. Is there an association between occlusion and periodontal destruction?: Yes - occlusal forces can contribute to periodontal destruction / S. K. Harrel, M. E. Nunn, W. W. Hallmon // Journal of American Dental Association. - 2006. - Vol. 137, N. 10. P. 1380, 1382, 1384

11. Harrel S. K. Occlusal forces as a risk factor for periodontal disease / S. K. Harrel // Periodontology 2000. - 2003. - Vol. 32. - P. 111-117.

12. Harrel S. K. The association of occlusal contacts with the presence of increased periodontal probing depth / S. K. Harrel, M. E. Nunn // Journal of Clinical Periodontology. - 2009. - Vol. 36, N. 12. - P. 1035- 1042. 13. Harrel S. K. The effect of occlusal discrepancies on periodontitis. II. Relationship of occlusal treatment to the progression of periodontal disease / S. K. Harrel, M. E. Nunn // Journal of Periodontology. - 2001. Vol. 72, N. 4. - P. 495-505.

14. Hyperocclusion stimulates osteoclastogenesis via CCL2 expression / K. T. Goto, H. Kajiya, T. Nemoto [et al.] // Journal of Dental Research. - 2011. - Vol. 90, N. $6 .-$ P. $793-798$.

15. Hyperocclusion up-regulates CCL3 expression in CCL2- and CCR2-deficient mice / T. Tsutsumi, H. Kajiya, K. T. Goto [et al.] // Journal of Dental Research. - 2013. - Vol. 92, N. 1. - P. 65-70.

16. Jin L. J. Clinical diagnosis of trauma from occlusion and its relation with severity of periodontitis / L. J. Jin, C. F. Cao // Journal of Clinical Periodontology. 1992. - Vol. 19, N. 2. - P. 92-97.

17. Naert I. Occlusal overload and bone/implant loss / I. Naert, J. Duyck, K. Vandamme // Clinical Oral Implants Research. - 2012. - N. 6. - P. 95-107.

18. Occlusal adjustment associated with periodontal therapy - a systematic review / A. M. Foz, H. P. Artese, A. C. Horliana [et al.] // Journal of Dentistry. - 2012. Vol. 40, N. 12. - P. 1025-1035.
19. Occlusal hypofunction causes periodontal atrophy and VEGF/VEGFR inhibition in tooth movement / R. Usumi-Fujita, J. Hosomichi, N. Ono [et al.] // The Angle Orthodontist. - 2013. - Vol. 83, N. 1. - P. 48-56. 20. Occlusial considerations in periodontics / S. J. Davies, R. J. Gray, G. L. Linden, J. A. James // British Dental Journal. - 2001. - Vol. 191, N. 11. - P. 597-604.

21. Occlusial interventions for periodontitis in adults / P. Weston, Y. A. Yaziz, D. R. Moles, I. Needleman // Cochrane Database of Systematic Reviews. - 2008. Vol. 3, N.16. - P. 100-110.

22. Periodontal ligament cells under mechanical stress induce osteoclastogenesis by receptor activator of nuclear factor kappaB ligand up-regulation via prostaglandin E2 synthesis / H. Kanzaki, M. Chiba, Y. Shimizu, H. Mitani // Journal of Bone Mineral Research. - 2002. - Vol.17, N. 2. - P. 210-220.

23. Prosthetic rehabilitation of patients with history of moderate to severe periodontitis: a long-term evaluation / C. Graetz, F. Schwendicke, M. Kahl [et al.] // Journal of Clinical Periodontology. - 2013. - Vol. 40, N. 8. P. $799-806$.

24. Sanz M. Occlusion in a periodontal context / M. Sanz // International Journal of Prosthodontics. 2005. - Vol.18, N. 4. - P. 309-310.

25. Saravanan R. Trauma from occlusion - An orthodontist's perspective / R. Saravanan, Prajeeth J. Babu, P. Rajakumar // Journal of Indian Society of Periodontology. - 2010. - Vol. 14, N. 2. - P. 144-145. 26. Secondary trauma from occlusion and periodontitis/ M. Branschofsky, T. Beikler, R. Schafer [et al.] // Quintessence International. - 2011. - Vol. 42, N. 6. P. 515-522.

27. Serio F. G. Periodontal trauma and mobility. Diagnosis and treatment planning / F. G. Serio, C. E. Hawley // Dental Clinics of North America. 1999. - Vol. 43, N. 1. - P. 37- 44.

28. Shulman J. Occlusal discrepancies / J. Shulman // Journal of American Dental Association. - 2007. Vol. 138, N. 1. - P. 30-32. 